\title{
Energy Recovery from Polyethylene Terephthalate(PET) Recycling Process
}

\author{
Radin Maya Saphira Radin Mohamed (Author) \\ Department of Water and Environmental Engineering, \\ Faculty of Civil and Environmental Engineering, \\ Universiti Tun Hussein Onn Malaysia, \\ 86400 Parit Raja, Batu Pahat, Johor, Malaysia \\ maya@uthm.edu.my
}

\author{
Anwaruddin Ahmed Wurochekke (Co-Author) \\ Department of Water and Environmental Engineering, \\ Faculty of Civil and Environmental Engineering, \\ Universiti Tun Hussein Onn Malaysia, \\ 86400 Parit Raja, Batu Pahat, Johor, Malaysia \\ yadembo02@yahoo.com
}

\author{
Gazala Sanusi Misbah (Co-Author) \\ Department of Water and Environmental Engineering, \\ Faculty of Civil and Environmental Engineering, \\ Universiti Tun Hussein Onn Malaysia, \\ 86400 Parit Raja, Batu Pahat, Johor, Malaysia \\ maya@uthm.edu.my
}

Amir Hashim bin Mohd. Kassim (Co-Author)

Department of Water and Environmental Engineering, Faculty of Civil and Environmental Engineering, Universiti Tun Hussein Onn Malaysia, 86400 Parit Raja, Batu Pahat, Johor, Malaysia amir@uthm.edu.my

\begin{abstract}
Solid waste generation especially from plastics increase every year due to the current consumption habit in the society. The improper disposal of plastics has been a major concern to environment as they are not easily degradable. In this study, energy derived from Polyethylene Terephthalate (PET) plastic bottle recycling process were studied. Raw and used PET samples were produced by using injection moulding machine. The amount of energy recovered upon production was calculated by using Universal Testing Machine. The effect of temperature and pressure during production on raw and used PET plastics were measured. Temperature at $260^{\circ} \mathrm{C}$ and $7 \mathrm{Mpa}$ pressure gave highest energy production. The results of raw and used PET samples exhibit comparable amount of energy $0.8 \mathrm{~J}$ and $2.044 \mathrm{x}$ $10^{-4} \mathrm{MJ} / \mathrm{Kg}-2.0635 \times 10^{-4} \mathrm{MJ} / \mathrm{Kg}$ respectively. Generally, used PET $\left(260^{\circ} \mathrm{C}\right.$ and $\left.6 \mathrm{Mpa}\right)$ were to be reprocessed to regain the significant energy production that are lost upon discarding. Mechanical tests were conducted on the PET and were compared with HDPE to study the temperature effect on the mechanical properties. PET show decrement of average hardness value 8.99 $\%$ after filled with hot water at $100{ }^{\circ} \mathrm{C}$. The increased of hot water filling temperature subsequently reduced the tensile strength and hardness value for both HDPE and PET. From this experiment, it is expected that energy recovery derived through the PET recycling can be optimized as part of an integrated waste management strategy.
\end{abstract}

Keywords- PET, plastic, plastic recycling, energy recovery

\section{INTRODUCTION}

With the current habit of consumption, the generation of plastic in society increase every year. Waste is generated from various sources like, domestic, industrial and commercial centers [1, 2], which is becoming one of the most relevant is sues for modern society municipalities because of its social, political, and economical impact [3]. The organic component of municipal solid waste may not be too much of a problem due to its degradability while the plastic solid waste is quite problematic [4]. Because this is non-biodegradable substance therefore it stays long in the environment. Plastics are organic polymeric materials consisting of giant organic molecules where plastic materials can be formed into shapes by a variety of processes and possess a number of extremely desirable characteristics $[5,6]$.

In overcoming the problem of plastic waste a number of technologies have been investigated to restore the issue. Various technologies such as landfilling, gasification and recycling towards energy recovery were studied [7, 8, 9]. Among the options plastic recycling is considered sustainable practice due to its numerous benefits and also environmentally less hazardous which is friendlier among other methods, because it has material and energy recovery $[9,10]$.

The energy represents in the plastic during production and the recycling products may be energy efficient [11]. According to Impee (2005) [12], it takes less energy to manufacture a plastic ketchup bottle than a glass ketchup bottle and since plastics are lightweight, it takes less energy to transport a truckload of plastic ketchup bottles than a truckload of glass ketchup bottle. However, the energy production process of PET includes embodied energy, total plant energy, energy mortgage to the production plant then the PET granules, aggregate embodied energy plus the energy mortgage, total plant energy to the bottle blow molding plant and to the final product.

Hence, recycling is a viable alternative in getting back some of this energy in the case of some polymers such as HDPE, PET, PVC etc. Furthermore, the price of used plastics were about half that of raw material produced as seen in Table I. It can be seen that they provide cost effective by the used 
PET rather than produce them from raw materials. Hence, the required energy consumption for recycling plastic is less than the energy consumed in the production of the same resin from raw feedstock [13].

Therefore, the main objectives of this study is to measure the energy recovery between raw polyethylene terephthalate (PET) plastic and used PET plastic bottle in different temperatures and pressure. The aim is to evaluate the energy production from the raw and used PET during the recycling process. This study seeks to find out the potential of energy recovery which can lead to conservation of natural resources and establishment of better waste management system.

Table I. Energies and prices of raw and used plastics

[12]

\begin{tabular}{|c|c|c|c|c|}
\hline $\begin{array}{l}\text { Commodity } \\
\text { Plastics }\end{array}$ & $\begin{array}{l}\text { Embodied } \\
\text { energy, } \\
\text { raw } \\
\text { material } \\
(\mathrm{MJ} / \mathrm{Kg})\end{array}$ & $\begin{array}{l}\text { Price, } \\
\text { raw } \\
\text { material } \\
(\$ / K g)\end{array}$ & $\begin{array}{l}\text { Embodied } \\
\text { energy, } \\
\text { used } \\
\text { material } \\
(\mathrm{MJ} / \mathrm{Kg})\end{array}$ & $\begin{array}{l}\text { Price, } \\
\text { used } \\
\text { material } \\
(\$ / K g)\end{array}$ \\
\hline HDPE & $77-85$ & $1.9-2.0$ & $\approx 35-45$ & $\begin{array}{l}0.84- \\
0.97\end{array}$ \\
\hline$\overline{\mathrm{PP}}$ & $75-83$ & $1.8-1.85$ & $\approx 35-45$ & $0.99-1.1$ \\
\hline PET & $79-88$ & $2.0-2.1$ & $\approx 60-64$ & $1.1-1.2$ \\
\hline$\overline{\mathrm{PS}}$ & $96-105$ & $1.5-1.6$ & $\approx 40-50$ & $\begin{array}{l}0.75- \\
0.86\end{array}$ \\
\hline PVC & $63-70$ & $1.4-1.5$ & $\approx 35-40$ & $\begin{array}{l}0.77- \\
0.99\end{array}$ \\
\hline
\end{tabular}

\section{MATERIALS AND METHOD}

\section{A. Sample collection and preparation}

Used PET and HDPE plastic bottles amounting up to 60 bottles of $1500 \mathrm{ml}$ liter size were collected in dust bins and were taken to laboratory, granulated into small pieces (< $10 \mathrm{~mm}$ ) using SLM 50FY plastic granulator, followed by washing in warm $\left(60^{\circ} \mathrm{C}\right)$ water with constant agitation for 2 hours [14]. The used HDPE was prepared to use for mechanical analysis with PET.

Sample of raw PET was supplied by polymer and ceramic laboratory Universiti Tun Hussein Onn Malaysia. Then pellets of raw, used PET and used HDPE were dried in an oven $12 \mathrm{~h}$ at $80{ }^{\circ} \mathrm{C}$ as according to method by [14]. The pellets and scraps were molded in the shape of ASTM D-790 and ASTM D-638 (Type I) test bars with Real Mini injection molding machine (model NP 7-1F). The dimension of rectangular shaped specimens of $10 \mathrm{~mm}$ in width, $80 \mathrm{~mm}$ in overall length, and 4 $\mathrm{mm}$ in thickness for raw and used PET flexural test samples were prepared by injection moulding. Apparently, the dimension of dumbbell shaped specimen of $12.7 \mathrm{~mm}$ in width at narrow section, $20 \mathrm{~mm}$ overall width, $80 \mathrm{~mm}$ gauge length,
$165 \mathrm{~mm}$ overall length and $3.5 \mathrm{~mm}$ thickness for both used PET and HDPE tensile test samples were also prepared by injection moulding. The typical molding conditions are as follows:

- $\quad$ Barrel (Injection) temperature: 250, 260 and $270{ }^{\circ} \mathrm{C}$

- Injection pressure: 6, 7 and $8 \mathrm{MPa}$

For this test experiment, there were 15 specimens each (raw and used PET) which were prepared for flexural test. There were five specimens of raw and used PET for three different ratios. Each ratio was moulded with a temperature $250^{\circ} \mathrm{C}, 260^{\circ}$ $\mathrm{C}$ and $270^{\circ} \mathrm{C}$ respectively. However, there were 5 specimens each (used PET and used HDPE) who were prepared for tensile and young modulus test. Hardness test were also conducted on the used PET and HDPE samples using Shore Durometer type $\mathrm{D}$ and at least triplicate readings were taken.

\section{B. Experimental set up and analysis}

Flexural strength, tensile strength and young modulus of PET was examined using a universal testing machine (UTM) brand (SHIMADZU) model (AG_1) as seen in Fig. I and II, to measure the energy and mechanical performance in the test samples. This equipment has maximu m capacity of $10 \mathrm{KN}$ with a load cell of $5 \mathrm{KN}$, a crosshead speed of $5 \mathrm{~mm} / \mathrm{min}$, and a gauge length of $80 \mathrm{~mm}$. These experimental computations data were compared using the data analys is tool in Microsoft excel 2007. The UTM (model A G-1) for flexural test, tensile strength and young modulus samples was used for the calculation of energy and mechanical performance. The machine movement and function was control by trapezium software and energy, tensile and young modulus calculation was shown on the computer screen attached to the machine.

Hardness was tested by using Shore Durometer type D as seen in Fig. III. This equipment uses spring to provide power at a certain awl that will determine the degree of violence in the test material. Durometer reads the scale of depth found in the materials and converted to linear scale with a value from 0 to 100 where each number represents the value of violence.

First, both UTM and computer were switched on. Then, specimen was placed on the supports using hand supports in vertical position. Machine bottom supports was adjusted to the specimen length. The data on all specimens were inserted into the computer system according to their file names and instructions. The system set the force and the position of support to zero positions by touch screen at monitor of the UTM. The test was run automatically by click 'begin test' on the software. The test stopped automatically after the specimen has fracture or break and data obtained from test was shown on the computer screen. Then the data and graph can be saved into PDF or MS excel format. 


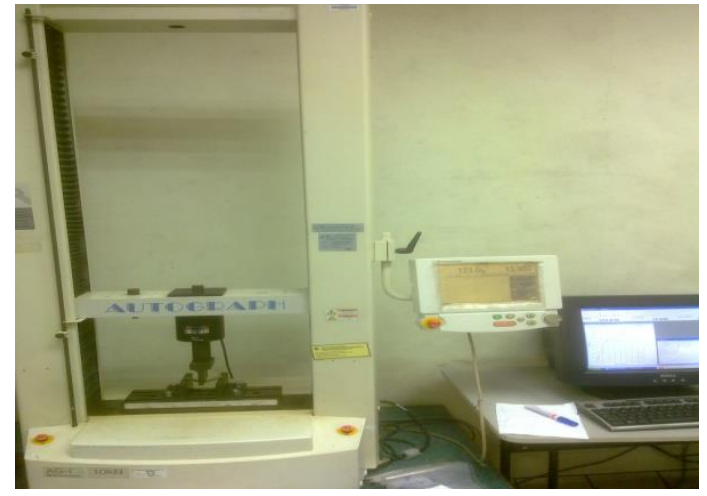

Figure I. Universal Testing Machine for Flexural test (Model AG-1)

Secondly, using the same UTM and computer, tensile test sample specimens were placed on the clipper using hand clipper in vertical position. Machine bottom clipper was adjusted so that it can clip the other side of the specimen. The procedure is repeated as in the first stage, result of tensile strength and young modulus were recorded.

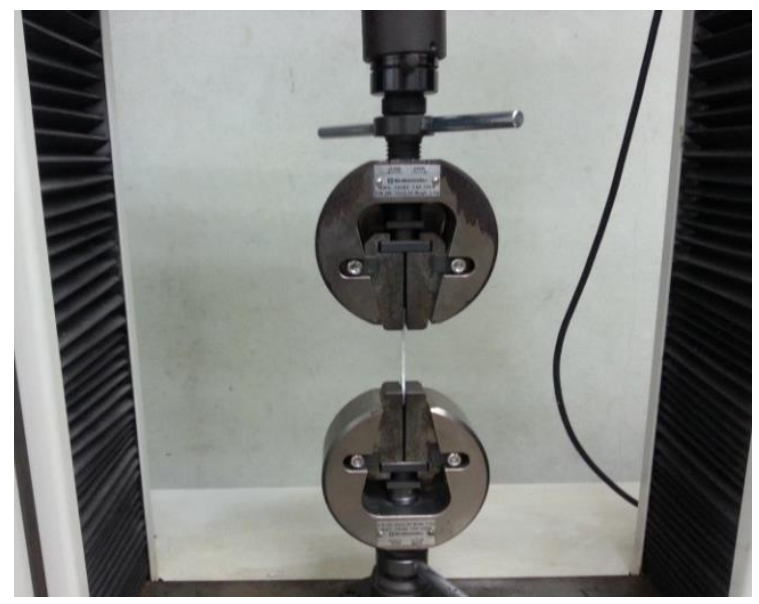

Figure II. Universal Testing Machine for Tensile and Young Modulus test (Model AG-1)

Thirdly, sample specimen was placed on a table with stable surface to ensure exact readings. Then, Durometer is hold by one hand and is pressed on the sample. Pressure direction must be ensured to be perpendicular to the sample surface as seen in Fig. III. Readings was taken for pressure in 1-2 seconds. To ensure exact readings, usually a few readings was taken.

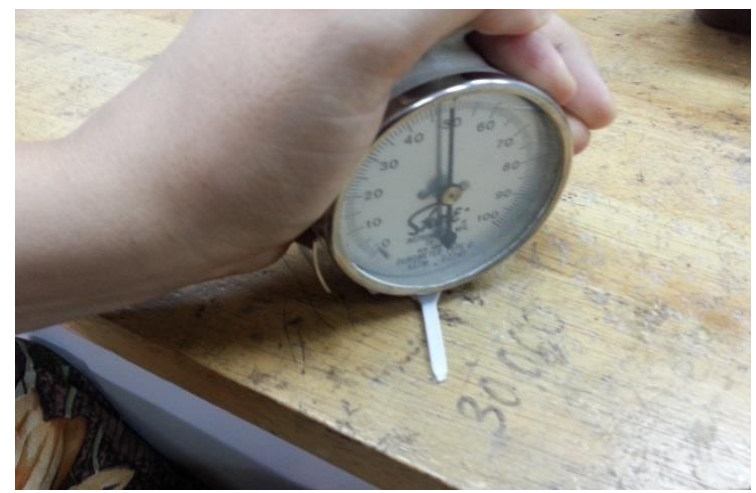

Figure III. Shore Durometer Type D for Hardness test

\section{RESULT AND DISCUSSION}

\section{A. Energy Recovery from PET Recycling Process}

Flexural test samples produced from injection moulding machine was analyzed for energy recovery. Average weight of samples for raw and used PET plastic produced at different temperatures was determined as presented in Table II, where temperatures were chosen from the light of literature [15]. However, another test samples produced from injection moulding machine were analyzed for mechanical performance; tensile strength and hardness.

Table II. Average Weight of Samples Produced from Raw and Used PET

\begin{tabular}{|c|c|c|c|}
\hline \multirow{3}{*}{$\begin{array}{c}\text { Type of } \\
\text { PET }\end{array}$} & \multicolumn{3}{|c|}{ Temperature } \\
\cline { 2 - 4 } & $250^{\circ} \mathrm{C}$ & $260^{\circ} \mathrm{C}$ & $270^{\circ} \mathrm{C}$ \\
\hline Raw PET & $4.2948 \times 10^{-}$ & $4.3051 \times 10^{-}$ & $4.4806 \times 10^{-}$ \\
& ${ }^{3} \mathrm{Kg}$ & ${ }^{3} \mathrm{Kg}$ & ${ }^{3} \mathrm{Kg}$ \\
\hline Used & $4.1585 \times 10^{-}$ & $4.2644 \times 10^{-}$ & $4.1684 \times 10^{-}$ \\
PET & ${ }^{3} \mathrm{Kg}$ & ${ }^{3} \mathrm{Kg}$ & ${ }^{3} \mathrm{Kg}$ \\
\hline
\end{tabular}

Mean energy between raw and used PET plasic after injected with moulding at different tempretures $\left(250-270{ }^{\circ} \mathrm{C}\right)$ was shown in Fig. IV and Table III. From the outcome of standard deviation and mean, it indicates that raw PET exhibits $1.66 \mathrm{~J}$ while $0.86 \mathrm{~J}$ represents the used PET moulded at $250{ }^{\circ} \mathrm{C}$. Meanwhile, 0.88J shows for both raw and used PET produced at $260^{\circ} \mathrm{C}$ has the same amount of energy. However, the raw exhibits $0.56 \mathrm{~J}$ while used PET exhibits $0.42 \mathrm{~J}$ when produced at $270{ }^{\circ} \mathrm{C}$. Therefore, this result shows plastic produced at $260{ }^{\circ} \mathrm{C}$ have the potential for more energy recovery, since both materials exhibits same amount of energy. Hence, used PET plastic should be reproduced at $260{ }^{\circ} \mathrm{C}$. These results show that the material properties of recyclate were as good as, and insome instances better than prime polymer [14]. Thus, used PET were sensitive to thermal and hydrolytic degredation than raw PET because they had a value of viscosity close to those of used PET when heated at high tempreture as in previous studies [15]. As such the need to compare raw and used PET is due to its wide spread use, especially in beverage industries. Used PET when compared with raw PET saves the environment from extrusion of natural resources, release of gases like $\mathrm{CO}_{2}$ into atmosphere during transporting and processing raw materials to/in the factory.

Apparently, as in the work of [12], states that processing energy between raw and used PET was relatively high, more fossil fuel energy was used in the production $79-88 \mathrm{MJ} / \mathrm{kg}$ for raw PET than 60-64 MJ/Kg for the used PET. Similarly, this research show similar outcome with some disparity due to different method, condition and quantity of samples during production. It indicates that the amount of $3.865 \times 10^{-4} \mathrm{MJ} / \mathrm{kg}$ and $2.068 \times 10^{-4} \mathrm{MJ} / \mathrm{Kg}$ for raw and used PET were produced at $250{ }^{\circ} \mathrm{C}$ respectively. Where production at $260{ }^{\circ} \mathrm{C}$ exh ibits 2.044 $\mathrm{x} 10^{-4} \mathrm{MJ} / \mathrm{Kg}$ for raw PET and $2.0635 \times 10^{-4} \mathrm{MJ} / \mathrm{Kg}$ for used PET while $1.2498 \times 10^{-4} \mathrm{MJ} / \mathrm{Kg}$ for raw PET and $1.0075 \times 10^{-}$ ${ }^{4} \mathrm{MJ} / \mathrm{Kg}$ for used PET produced at $270{ }^{\circ} \mathrm{C}$. The less energy to 
weight reflects the little weight of polymer samples of the usedd material, thereby limiting its use, because of this the contribution of recycling to current plastic consumption is small. Hence, encouragement towards recycling habit are economical and environmentally less hazardous to used polymers rather than produce them from raw materials.

Table III. Overall Mean Energy Production from Raw and Used PET

\begin{tabular}{|c|c|c|c|}
\hline \multicolumn{4}{|c|}{ Mean \pm Std Dev Energy Production from Raw and Used PET } \\
\hline \multirow{2}{*}{$\begin{array}{c}\text { Type of } \\
\text { PET }\end{array}$} & $250{ }^{\circ} \mathrm{C}$ & $260{ }^{\circ} \mathrm{C}$ & $270{ }^{\circ} \mathrm{C}$ \\
\cline { 2 - 4 } & $1.66 \mathrm{~J} \pm 0.51$ & $0.88 \mathrm{~J} \pm 0.54$ & $0.56 \mathrm{~J} \pm 0.20$ \\
\hline Raw PET & $0.86 \mathrm{~J} \pm 0.21$ & $0.88 \mathrm{~J} \pm 0.04$ & $0.42 \mathrm{~J} \pm 0.25$ \\
\hline Used PET & \multicolumn{2}{|c|}{ Tempere } \\
\hline
\end{tabular}

Std Dev: Standard Deviation

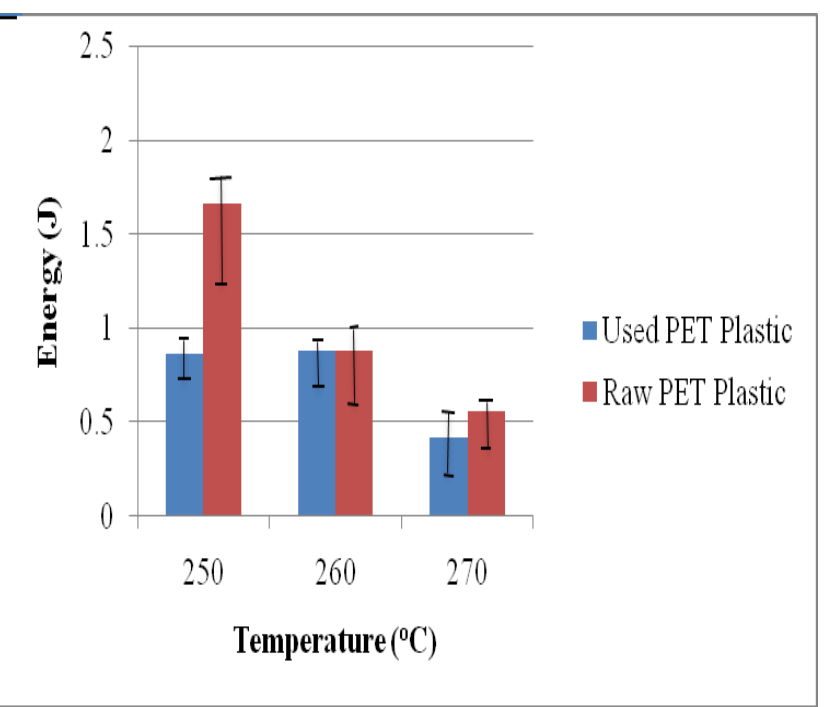

Figure IV. Mean Energy Production from Raw and Used PET

\section{B. Mechanical Analysis of PET}

Mean mechanical performance comparing between used HDPE and used PET plastic after injection moulding was shown in Fig. V and Table IV. From the outcome of mean, it indicates that used HDPE samples has tensile strength of $23 \mathrm{MPa}$ before filled with hot water while used PET plas tic has $36 \mathrm{MPa}$. Meanwhile, used HDPE samp les filled with hot water at temperature ranging between $50-100^{\circ} \mathrm{C}$ exhibits decrease in tensile strength from $21.385 \mathrm{MPa}$ at $50^{\circ} \mathrm{C}$ to $16.144 \mathrm{MPa}$ at $100^{\circ} \mathrm{C}$. However, used PET plastic sample filled in hot water from temperature $50^{\circ} \mathrm{C}-100^{\circ} \mathrm{C}$ also exhibits a decrease tensile strength from $36.46 \mathrm{MPa}$ to $33.144 \mathrm{MPa}$ accordingly. Yet, used PET samples has a higher tensile strength in all conditions. Therefore, the results shows that tensile strength of both samples decreases with increase in temperature. Hence, used PET plastic can stand a longer temperature effect than used HDPE plastic. As such, used PET plastic should be used for beverage packeging for longer period. These result show that PET plastic products were used by manufactures due to its strength, thermo-stability, resistance to temperature and transparency [16].
For Young modulus shown in Fig. V, used PET exhibit Young value of 1052.228 MPa while used HDPE exhibit 333.313 $\mathrm{MPa}$ which is three times less than PET value before filling in hot water. However, for samples filled in hot water temperature ranging from $50^{\circ} \mathrm{C}-100^{\circ} \mathrm{C}$, when tested exhibits a significant decrease in Young value from 947.054-705.114 $\mathrm{MPa}$ and 403.507-157.181 MPa for used PET and HDPE plastic accordingly. Therefore, used PET plastic show a significant Young value than used HDPE plastic in its dimensional change when subjected to a tensile load [17].

Overall, used PET plastic show better mechanical performance from the samples tested than the used HDPE plastic under a tensile load. Apparently, at normal temperature or high temperature used PET plastic exhibits significant mechanical resistance to temperature, as it show higher value than used HDPE plastic. Therefore this makes used PET plastic a better option for both manufactures and consumers because of its good mechanical properties, light weigth and transparency. Hence, used PET plastic will drive a good economic and eco-friendly environment. Because less raw materials will be needed by the manufactures and the production process of used PET is easier/cheaper than the raw PET plastic.

Table IV. Overall Mean Values of used HDPE and Used PET Plastic

\begin{tabular}{|l|c|r|r|r|r|r|r|}
\hline \multicolumn{7}{|c|}{$\begin{array}{l}\text { Mean Values of Used HDPE and PET at Different } \\
\text { Temperature Filling with Hot Water }\end{array}$} \\
\hline & \multicolumn{7}{|c|}{ Temperature } \\
\cline { 2 - 7 } & $\begin{array}{l}\text { Normal } \\
\text { Temp. }\end{array}$ & $50^{\circ} \mathrm{C}$ & $60^{\circ} \mathrm{C}$ & $70^{\circ} \mathrm{C}$ & $80^{\circ} \mathrm{C}$ & $90^{\circ} \mathrm{C}$ & $10^{\circ} \mathrm{C}$ \\
\hline $\begin{array}{l}\text { Tensile } \\
\text { Strength } \\
\text { (Used } \\
\text { HDPE) }\end{array}$ & 23.323 & 21.385 & 19.836 & 19.041 & 17.967 & 16.708 & 16.144 \\
\hline $\begin{array}{l}\text { Tensile } \\
\text { Strength } \\
\text { (Used } \\
\text { PET) }\end{array}$ & 36.46 & 36.126 & 35.751 & 35.241 & 34.303 & 33.375 & 33.144 \\
\hline $\begin{array}{l}\text { Young } \\
\text { Modulus } \\
\text { (Used } \\
\text { HDPE) }\end{array}$ & 333.313 & 403.507 & 409.391 & 346.046 & 257.772 & 233.008 & 157.181 \\
\hline $\begin{array}{l}\text { Young } \\
\text { Modulus } \\
\text { (Used } \\
\text { PET) }\end{array}$ & 1052.228 & 947.054 & 913.619 & 846.046 & 782.583 & 744.665 & 705.114 \\
\hline
\end{tabular}




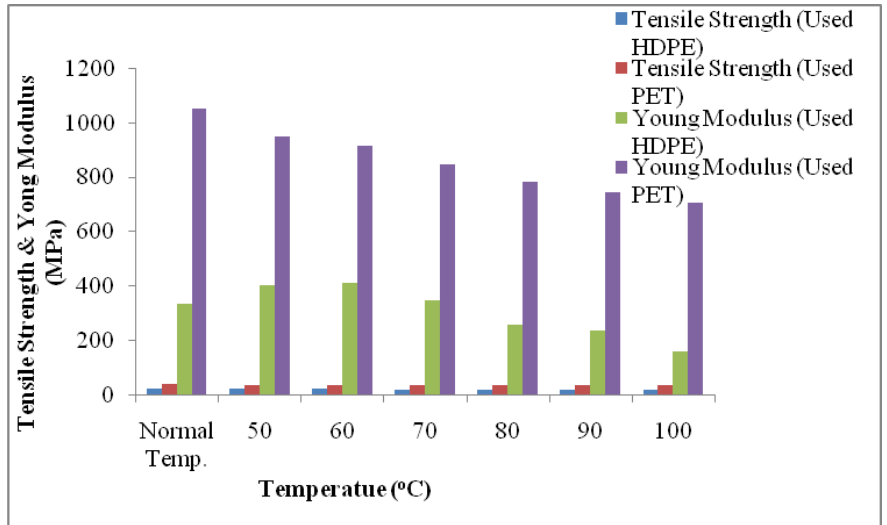

Figure V. Tensile Strength and Young Modulus of used HDPE and Used PET Plastic

The hardness test results is shown in Fig. VI and Table V. It indicates that used PET plastic at normal temperature and used HDPE plastic show average Durometer index value 75.6 and 54.8 respectively. However, after the samples were filled in hot water at $50^{\circ} \mathrm{C}$, the hardness was changed to 72.8 and 54.2 for both used PET and used HDPE plastic, respectively. Mean values of both PET and HDPE changed at temperature of $100^{\circ} \mathrm{C}$ filling with hot water were 68.8 and 47.4. In a similar result shown in Fig. VII for percentage change in hardness, used HDPE plastic when filled with hot water at $50^{\circ} \mathrm{C}$ with value of 3.7 and $7.19 \%$ respectively. However, they were changed significantly when it was filled with hot water at $100^{\circ} \mathrm{C}$ with 8.99 and $18.84 \%$. Therefore, mechanical properties of used HDPE plastic are affected more with change in temperature. Hence, used PET plastic is more suitable for packaging drinks like beverages, cosmetic containers and household containers because it exhibits little decreament in its mechanical properties due to temperature change.

Table V. Overall Mean Durometer Values of Used HDPE and Used PET Plastic

\begin{tabular}{|c|c|c|c|c|c|c|c|}
\hline \multicolumn{8}{|c|}{$\begin{array}{c}\text { Mean Durometer Values of Used HDPE and PET at Different } \\
\text { Temperature Filling with Hot Water }\end{array}$} \\
\hline \multirow{2}{*}{$\begin{array}{c}\text { Materi } \\
\text { al }\end{array}$} & \multicolumn{7}{|c|}{ Temperature } \\
\hline & $\begin{array}{l}\text { Normal } \\
\text { Temp. }\end{array}$ & $50^{\circ} \mathrm{C}$ & $60^{\circ} \mathrm{C}$ & $70^{\circ} \mathrm{C}$ & $80^{\circ} \mathrm{C}$ & $90^{\circ} \mathrm{C}$ & $100^{\circ} \mathrm{C}$ \\
\hline $\begin{array}{r}\text { Used } \\
\text { HDPE }\end{array}$ & 54.8 & 54.2 & 52.2 & 50.8 & 49.4 & 48.4 & 47.4 \\
\hline $\begin{array}{l}\text { Used } \\
\text { PET }\end{array}$ & 75.6 & 72.8 & 72 & 71.6 & 71.2 & 70 & 68.8 \\
\hline \multicolumn{8}{|c|}{$\begin{array}{l}\text { \% Change in Hardness of Used HDPEandPET at Different Temperature } \\
\text { Filling }\end{array}$} \\
\hline $\begin{array}{c}\text { Used } \\
\text { HDPE }\end{array}$ & 0 & 7.19 & 10.62 & 13.01 & $\begin{array}{c}15.4 \\
1\end{array}$ & $\begin{array}{c}16.4 \\
4\end{array}$ & 18.84 \\
\hline $\begin{array}{l}\text { Used } \\
\text { PET }\end{array}$ & 0 & 3.7 & 4.76 & 5.29 & 5.82 & 7.41 & 8.99 \\
\hline
\end{tabular}

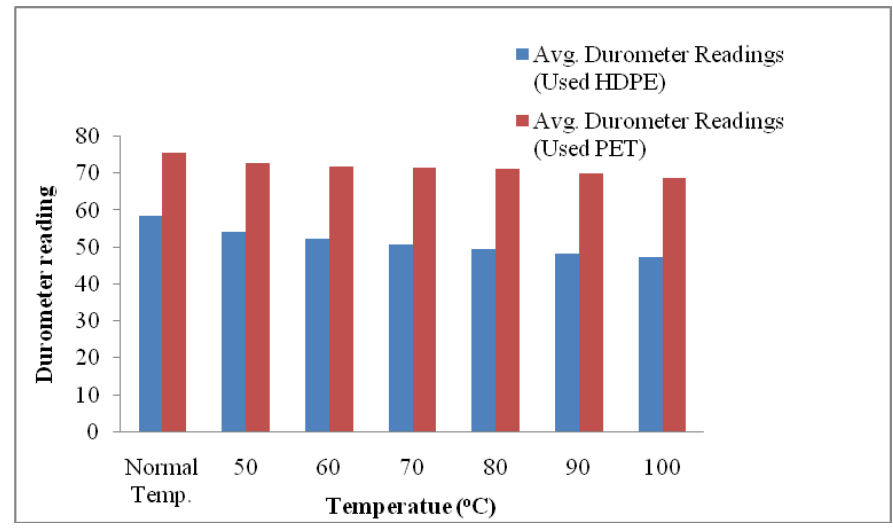

Figure VI. Hardness readings of Used HDPE and Used PET Plastic

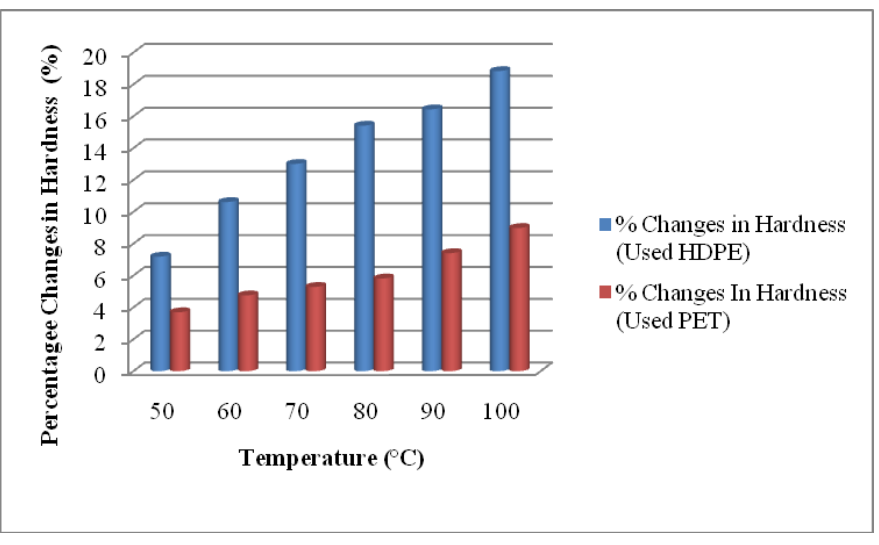

Figure VII. Percentage Change in Hardness of Used HDPE and Used PET Plastic

\section{CONCLUSIONS}

Raw PET samples produced at $250{ }^{\circ} \mathrm{C}$ exhibits higher energy during testing $(2.5 \mathrm{~J})$ compared to used PET samples $(1.79 \mathrm{~J})$. For samples produced at $260{ }^{\circ} \mathrm{C}$ the energy produced was $0.88 \mathrm{~J}$. However, for samples produced at $270{ }^{\circ} \mathrm{C}$, energy derived were $0.8 \mathrm{~J}$ and $0.7 \mathrm{~J}$, respectively. Similarly, energy to weight exhibits $2.044 \times 10^{-4} \mathrm{MJ} / \mathrm{Kg}$ and $2.0635 \times 10^{-4} \mathrm{MJ} / \mathrm{Kg}$ for raw and used PET, respectively. However, in all cases they were comparable amount of the energies according to the parameters of production $\left(260{ }^{\circ} \mathrm{C}\right.$ and $\left.7 \mathrm{Mpa}\right)$. Therefore, used PET were reprocessed at $260{ }^{\circ} \mathrm{C}$ and $7 \mathrm{Mpa}$ to recover significant energy productions that were lost upon discarding.

Mechanical tests were conducted on the PET and were compared with HDPE to study the temperature effect on the mechanical properties of HDPE and PET as package material. For hardness test, samples of HDPE without hot water filling gave the decrement in average value of hardness $18.84 \%$ when filled with hot water $100{ }^{\circ} \mathrm{C}$. Meanwhile PET show decrement of average hardness value $8.99 \%$ after filled with hot water at $100{ }^{\circ} \mathrm{C}$. The tensile strength for HDPE and PET both has $30.78 \%$ and $9.17 \%$ of decrement. From the stress-strain graph for HDPE, it shows ductile fracture with increment in the elasticity properties with the increasing of hot water filling temperature.

Hence, effectiveness of energy recovered from this research proved, post-consumer plastic (PET) bottles can be mechanically used rather than landfilling. As such, if the waste 
recovered in large quantity it can conserve the extrusion of raw materials from the environment. It is essential to integrate waste management schemes in the production cycle of plastics, whilst recycling is considered a sustainable practice, less greenhouse gas emissions, more energy security. Therefore, plastic resistance to natural degradation and introduction to recycling concept, thereby energy recovery is limited and might be considered in the developmental stages, especially in the case of plastic solid waste.

\section{ACKNOWLEDGMENT}

We thank Mohamed Ahmed Ebrahem Yami for the mechanical experiments and analysis. The author wish to express thanks to the staff at the Environmental Engineering Laboratory and Material lab, and also financial support from the Universiti Tun Hussein Onn Malaysia for this project.

\section{REFERENCES}

[1] S. Keser, S. Duzgun, and A. Aksoy, "Application of spatial and nonspatial data analysis in determination of the fact ors that impact municipal solid waste generat ion rates in Turkey," Waste management. New York, N.Y., vol. 32(3), pp. 359-71, 2012.J. Clerk Maxwell, A Treatise on Electricity and Magnetism, 3rd ed., vol. 2. Oxford: Clarendon, 1892, pp.68-73.

[2] K. M. Zia, H. N. Bhatti, and I. Ahmad Bhatti, "Methods for polyurethane and polyurethane composites, recycling and recovery," A review. Reactive and Functional Polymers, vol. 67(8), pp. 675-692, 2007.K Elissa, "Title of paper if known," unpublished.

[3] G. Ghiani, D. Laganà, E. Manni, and C. Triki, "Capacitated location of collection sites in an urban waste management system," Waste management. New York, N.Y., vol. 32(7), pp. 1291-6, 2012.

[4] T. Leejarkpai, U. Suwanmanee, Y. Rudeekit, and T. Mungcharoen, "Biodegradable kinetics of plastics under controlled composting conditions," Waste management. New York, N.Y., vol. 31(6), pp. 115361, 2011.

[5] P Action, (practical action).. "Recycling of plastics," The Schumacher Centre For Technology \& Development, January 2012

[6] C. Mugabo, and C. Uwamahoro, "An assessment study for the status of polythene and pet bottles waste in kigali," 2011.

[7] R. Couth, and C. Trois, "Sustainable waste management in Africa through CDM projects," Waste management. New York, N.Y., vol. 32(11), pp. 2115-2125,2012.

[8] J.-W. Kim, T.-Y. Mun, J.-O. Kim, and J.-S. Kim, "Air gasification of mixed plastic wastes using a two-stage gasifier for the production of producer gas with lowtar and a high caloric value," Fuel. Vol. 90(6), pp. 2266-2272, 2011

[9] A. Demirbas, "Waste management, waste resource facilities and waste conversion processes," Energy Conversion and Management. Vol. 52(2), pp. 1280-1287, 2011.

[10] S.M. Al-Salem, P. Lettieri, and J. Baeyens, "The valorization of plastic solid waste (PSW) by primary to quaternary routes: From re-use to energy and chemicals," Progress in Energy and Combustion Science. Vol. 36(1), pp. 103-129, 2010.

[11] D. Briassoulis, M. Hiskakis, E. Babou, S. K. Antiohos, and C. Papadi, "Experimental investigation of the quality characteristics of agricultural plastic wastes regarding their recycling and energy recovery potential," Waste management. New York, N.Y., vol. 32(6), pp. 1075-90, 2012.

[12] P. Impee, "Recycling of plastics," The impee project university of cambridge. 2005 .

[13] T. Takoungsakdakun, and S. Pongstabodee, "Separation of mixed post consumer PET-POM-PVC plastic waste using selective flotation," Separation and Purification Technology, vol. 54(2), pp. 248-252, 2007.

[14] C. A. Ambrose, R. Hooper, A. K. Potter, and M. M. Singh, "Diversion from landfill : quality products from valuable plastics," vol. 36, pp. 309$318,2002$.
[15] N. Torres, J. J. Robin, and B. Boutevin, "Study of thermal and mechanical properties of raw and usedd poly(ethylene terephthalate) before and after injection molding," European Polymer Journal. Vol. 36(10), pp. 2075-2080, 2000.

[16] J. C. Selke, and R. Hernandez, "Properties, Processing, application, and Regulation," Hanser Gardner Publications. $2^{\text {nd }}$ ed, 2004.

[17] D. Weckström, D. "Changes in Mechanical Properties of Recycled Polypropylene." Thesis Plastic Technology. Arcada-University of Applied Sciences, 2012.

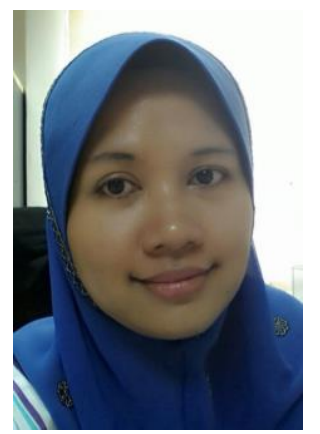

Dr. Radin Maya Saphira Radin Mohamed is a senior lecturer at Dept. of Water \& Environmental Engineering, Faculty of Civil \& Environmental Engineering, Universiti Tun Hussein Onn Malaysia. She did her $\mathrm{PhD}$ in Environmental Engineering (Greywater Recycling/Reuse for Irrigation), at Murdoch University, Perth, Australia. MEng (Research) in Civil Engineering (Environmental) with thesis titled 'River Modelling for Water quality in Bekok River' from College University Tun Hussein Onn Malaysia and BSc (Hons) in Industrial Chemistry, University Technology of Malay sia.

Dr. Radin Maya Saphira's research involves issues related to solid waste, water management, effluent, and soil qualities as well as their impact on the environment, and the search for practices to improve environmental quality related to contamination by different sources. In the last few years she has extended her research interest to recovering energy potential from the PET recycling process. 